\title{
Onco-fertility and personalized testing for potential for loss of ovarian reserve in patients undergoing chemotherapy: proposed next steps for development of genetic testing to predict changes in ovarian reserve
}

\author{
Bei Sun ${ }^{1}$ and John Yeh $^{2^{*}}$ (D)
}

\begin{abstract}
Women of reproductive age undergoing chemotherapy face the risk of irreversible ovarian insufficiency. Current methods of ovarian reserve testing do not accurately predict future reproductive potential for patients undergoing chemotherapy. Genetic markers that more accurately predict the reproductive potential of each patient undergoing chemotherapy would be critical tools that would be useful for evidence-based fertility preservation counselling. To assess the possible approaches to take to develop personalized genetic testing for these patients, we review current literature regarding mechanisms of ovarian damage due to chemotherapy and genetic variants associated with both the damage mechanisms and primary ovarian insufficiency. The medical literature point to a number of genetic variants associated with mechanisms of ovarian damage and primary ovarian insufficiency. Those variants that appear at a higher frequency, with known pathways, may be considered as potential genetic markers for predictive ovarian reserve testing. We propose developing personalized testing of the potential for loss of ovarian function for patients with cancer, prior to chemotherapy treatment. There are advantages of using genetic markers complementary to the current ovarian reserve markers of $\mathrm{AMH}$, antral follicle count and day 3 FSH as predictors of preservation of fertility after chemotherapy. Genetic markers will help identify upstream pathways leading to high risk of ovarian failure not detected by present clinical markers. Their predictive value is mechanism-based and will encourage research towards understanding the multiple pathways contributing to ovarian failure after chemotherapy.
\end{abstract}

Keywords: Oncofertility, Fertility preservation counseling, Ovarian reserve testing, Chemotherapy, Ovarian damage

\footnotetext{
* Correspondence: john.yeh.md@gmail.com

${ }^{2}$ Division of Reproductive Endocrinology and Infertility, Department of Obstetrics \& Gynecology, University of Massachusetts Medical School, UMass Memorial Medical Center, 119 Belmont Street, Worcester, MA 01605, USA Full list of author information is available at the end of the article
}

C C The Author(s). 2021 Open Access This article is licensed under a Creative Commons Attribution 4.0 International License, which permits use, sharing, adaptation, distribution and reproduction in any medium or format, as long as you give appropriate credit to the original author(s) and the source, provide a link to the Creative Commons licence, and indicate if changes were made. The images or other third party material in this article are included in the article's Creative Commons licence, unless indicated otherwise in a credit line to the material. If material is not included in the article's Creative Commons licence and your intended use is not permitted by statutory regulation or exceeds the permitted use, you will need to obtain permission directly from the copyright holder. To view a copy of this licence, visit http://creativecommons.org/licenses/by/4.0/. The Creative Commons Public Domain Dedication waiver (http://creativecommons.org/publicdomain/zero/1.0/) applies to the data made available in this article, unless otherwise stated in a credit line to the data. 


\section{Search strategy and selection criteria}

A total of 373 papers were reviewed. For the section on mechanism of chemotherapy-induced damage, the authors performed PubMed searches using the following key words: chemotherapy, induced, ovarian insufficiency, mechanism. No time limits were placed on the time of publication and 87 results were obtained. Animal and clinical studies as well as references from review articles that evaluate the mechanism of chemotherapy-induced ovarian damage were selected. For the sections on genetic association with ovarian insufficiency, the authors performed PubMed searches using the following key words: genetic, variants, ovarian insufficiency. No time limits were placed on the time of publication and 286 results were obtained. Animal and clinical studies that report a genetic association with ovarian insufficiency were selected.

\section{Introduction}

The probability of premenopausal women to develop any type of invasive cancer is approximately 6\%, among which breast cancer is the most common [1]. Chemotherapy as part of the treatment induces ovarian dysfunction [2]. In 2013 globally, the number of women of reproductive age was 1.8 billion and this number is expected to grow to 2 billion by 2025 [3]. Based on these statistics, we extrapolate that more than 100 million women worldwide are at risk to chemotherapy-induced ovarian dysfunction and may seek fertility preservation. A mixed retrospective and prospective study of 102 women who underwent chemotherapy reported a $77.9 \%$ incidence of irreversible amenorrhea 12 months after completion of chemotherapy [4]. Fertility preservation counseling remains challenging and centers around the ovarian reserve of each patient [5]. Various chemotherapy regimens each presents with a different level of risk of loss of ovarian reserve [6]. In addition, patients clinically present with variable susceptibility to ovarian dysfunction. Helping patients understand their baseline and predicted post-chemotherapy reproductive potential requires clinical markers that accurately assess individual susceptibility to ovarian dysfunction.

Current ovarian reserve testing relies mainly on biochemical tests and ultrasound imaging [7]. For example, molecular markers such as anti-mullerian hormone $(\mathrm{AMH})$ and inhibin have been reported to be associated with chemotherapy-induced ovarian damage and reproductive aging [8-11]. While such tests have a high predictive value in high-risk populations, they are not routinely used in clinics to serve the general population. An editorial has suggested the use of genetic markers to predict outcome of ovarian function after chemotherapy [12]. As the genetic basis of premature ovarian insufficiency continues to be explored [13-15], genetic markers can be used in addition to ovarian reserve testing to help establish a more comprehensive baseline. Genetic and molecular pathways involved in chemotherapy-induced ovarian damage have been discussed in several studies [2, 16, 17]. We review the mechanism of ovarian damage and the associated genes as potential markers. We also review studies that investigate frequency of genetic mutations associated with premature ovarian dysfunction. An upstream regulator gene involved in chemotherapy-induced damage pathways whose mutations are frequently found would make an ideal candidate as a genetic marker. It can potentially help clinicians separate patients into the following categories for appropriate counseling: 1) higher theoretical genetic risk of loss of ovarian reserve at baseline 2) Increased theoretical ovarian reserve loss risk due to use of chemotherapy because of genetic mutations 3) lower theoretical genetic risk.

\section{Chemotherapy and genetic predisposition to ovarian insufficiency}

Mechanism of chemotherapy-induced damage

Ovarian dysfunction induced by chemotherapy was first reported in 1970s $[18,19]$. The mechanism of damage of these agents and protective measures have since been investigated [20-24]. Direct toxicity leading to apoptosis of oocytes and granulosa cells as well as accelerated follicle activation have emerged as mechanisms of chemotherapy-induced ovarian dysfunction (Fig. 1). In the case of breast cancer for example, more chemotherapeutic agents and more combinations of these agents have been approved over time. The effect of these agents on fertility and the mechanism of their damage on the ovaries have been investigated (Table 1). Both apoptosis and follicle overactivation seem to play a role in ovarian reserve depletion in the use of some agents. To what percentage of ovarian damage is each mechanism responsible is not understood. It is likely to be specific to each chemotherapeutic agent and should be studied quantitatively in animals. Alternative additional mechanisms of ovarian damage should also be explored.

\section{Apoptosis of oocytes and granulosa cells}

Chemotherapeutic agents may induce DNA alterations. These agents have been reported to disproportionally affect follicles in various stages and stromal cells [16, 32]. Double stranded-DNA breaks are among the most severe DNA lesions induced by these agents [33]. These lesions effectively activate DNA repair system leading to either cell survival or apoptosis (Fig. 1A). Studies support apoptosis as an important mechanism underlying chemotherapy-induced depletion of ovarian reserve through knockout (KO) experiments of pro-apoptotic factors in animals. For example, Ngyuen et al. 


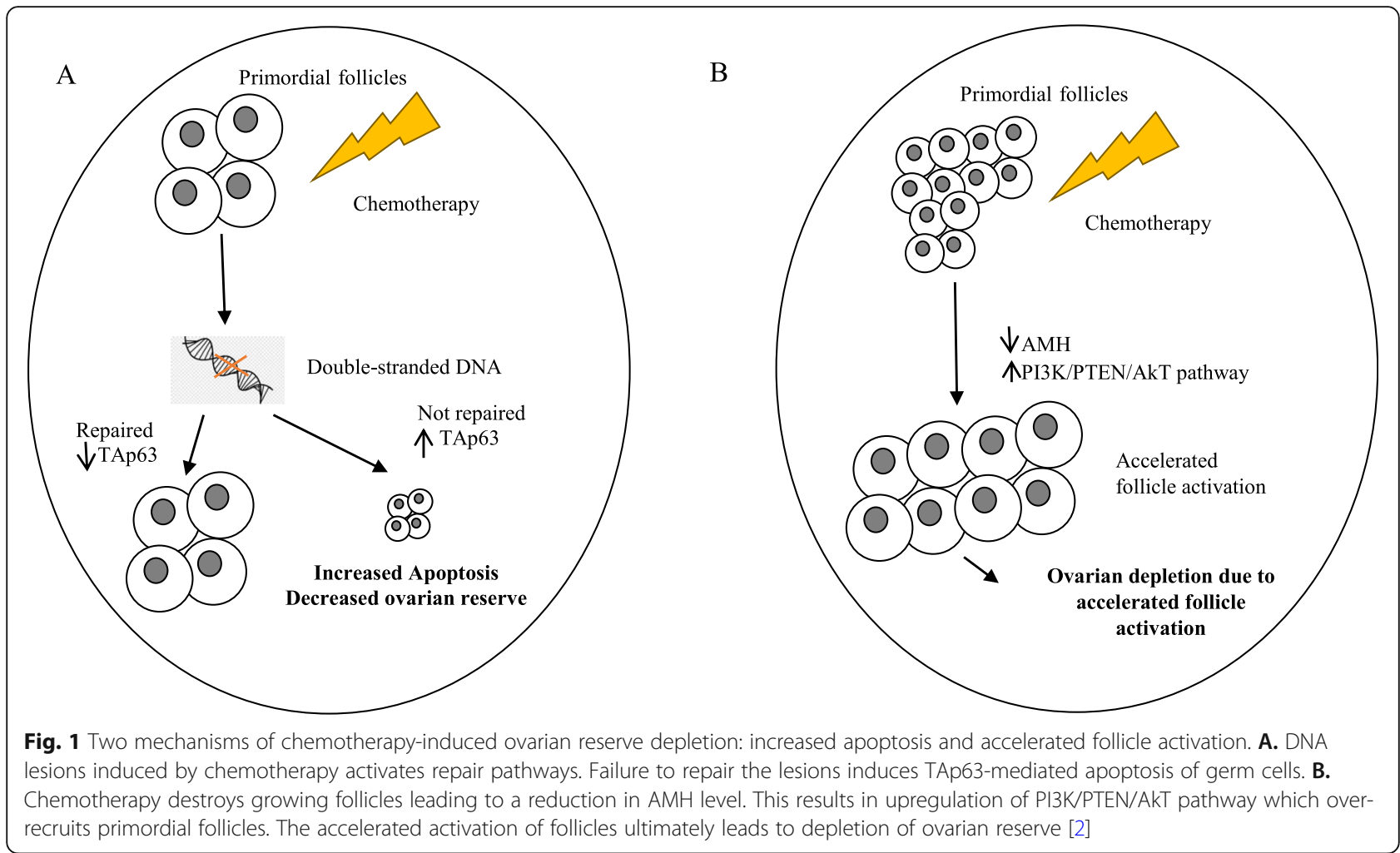

experimented with mouse knockout models of p53 upregulated modulator of apoptosis (PUMA) and its transcriptional activator TAp63 [34]. They exposed wildtype (WT), PUMA KO, and TAp63 KO mice to either cyclophosphamide or cisplatin treatments. Complete destruction of primordial follicles was observed in WT mice in contrast to close to $100 \%$ preservation of primordial follicles in PUMA KO mice. Preservation of primordial follicles in TAp63 $\mathrm{KO}$ mice was observed in cisplatintreated mice. Another study demonstrated mechanism of germinal vesicle oocyte apoptosis induced by doxorubicin through activation of caspase-12 and inactivation of DNA repair machinery such as poly-ADP ribose polymerase (PARP) [27]. Regulation of apoptosis of granulosa cells have also been studied extensively in animal models [35-39].

\section{Accelerated follicle activation}

Accelerated primordial follicle expenditure emerged as another important mechanism of chemotherapy-induced depletion of ovarian reserve (Fig. 1B). A study on cyclophosphamide-treated mice revealed that a wave of induced follicle activation rather than apoptosis is responsible for the rapid loss of ovarian reserve [40]. Maintenance of dormancy in primordial follicles underlies the reproductive lifespan of women. It is controlled by multiple signaling pathways that have been uncovered through animal studies [41-43]. Phosphatidylinositol 3-

Table 1 Chemotherapeutic agents used in breast cancer treatment cause ovarian damage

\begin{tabular}{llll}
\hline Chemotherapeutic Agent & Biological Target & Mechanism of Ovarian Damage & Reference \\
\hline Taxanes & microtubule & Apoptosis and suppression of follicle development & [25, 26] \\
Anthracyclines & DNA & Apoptosis, atresia and overactivation of ovarian follicles & {$[27,28]$} \\
Platinum agents & DNA & Both apoptosis and overactivation of ovarian follicles & [29] \\
Vinorelbine & microtubule & Unknown or none & [30] \\
Capecitabine & DNA & Unknown or none & [31] \\
Gemcitabine & DNA & Apoptosis of pre-antral/antral follicles & [32] \\
Ixabepilone & microtubule & Unknown & $\mathrm{N} / \mathrm{A}$ \\
Eribulin & microtubule & Unknown & $\mathrm{N} / \mathrm{A}$ \\
\hline
\end{tabular}


kinase (PI3K)/Akt signaling pathway negatively regulated by phosphatase and tensin homolog (PTEN) has been studied in mice and shown to be important in control of dormancy and implicated in chemotherapy-induced follicle burnout [43-45]. Suppressors of this follicleactivating pathway such as forkhead box O3a (FOXO3a), tuberous sclerosis protein 1 (TSC1) and tuberous sclerosis protein 2 (TSC2), when deactivated through phosphorylation, accelerates follicle recruitment and growth [41]. Phosphorylation of molecules in the pathway such as Akt and mTOR has a similar accelerating effect [43, $46,47]$. Chemotherapeutic agents have been shown to upregulate these activating pathways. For instance, cisplatin has been shown to decrease PTEN levels, leading to increased phosphorylation of Akt and subsequent pan activation of dormant primordial follicles in mice [48]. Another study showed that mTOR inhibitor cotreatment with cyclophosphamide preserves follicle count and fertility in mice through down-regulation of PI3K/Akt/ mTOR pathway [49]. There has been a lack of human studies to provide support for this mechanism. So far, an in vitro study of human ovarian follicle exposed to metabolites of cyclophosphamide showed enhanced follicle activation [50]. In addition, a recent cohort study of 96 women showed a significant reduction in nuclear expression of FOXO3a in primordial follicle oocytes in the ovaries of women exposed to alkylating agent chemotherapy, supporting accelerated follicle activation as a major mechanism of ovarian reserve depletion after exposure to alkylating agents [51].

\section{Genetic susceptibility to chemotherapy-induced damage Genes in DNA damage repair}

Homologous recombination and non-homologous end joining are mechanisms involved in repair of chemotherapy-induced severe DNA lesions in primordial follicles. Genetic defects that compromise the two repair pathways potentially increase patients' susceptibility to ovarian failure after chemotherapy. Major genes implicated in this susceptibility are discussed in the order of number of clinical evidences. BRCA1 and BRCA2 genes are crucial in repairing double-stranded DNA breaks. Their mutation carriers have a high risk of developing cancer. Furthermore, they often have fertility-related problems [52]. A cross-sectional study of 693 women showed that BRCA1 mutation carriers had on average 25\% lower AMH concentrations than non-carriers, suggesting that BRCA1 carriers had lower ovarian reserves than non-carriers [53]. No evidence of association was found between AMH concentration and BRCA2 mutation status in the same study. Another study surveyed 908 matched pairs of BRCA1 mutation carriers and noncarriers and found that carriers experienced earlier menopause [54]. Consistent with these findings, Oktay et al. reported a lower ovarian response rate and a lower number of eggs produced in BRCA1 mutation carriers compared to non-carriers under ovarian stimulation [55]. No association between BRCA2 mutations and the probability of low ovarian response was found in the study. Current studies consistently point to a strong association between BRCA1 mutation status and propensity of ovarian failure. For BRCA2, certain mutations are associated with total failure of ovarian development and appears to result in a more widespread ovarian damage either in utero or early stage of development $[56,57]$. Minichromosome maintenance complex component 8 and 9 (MCM8, 9) are another two genes involved in DNA repair that is associated with primary ovarian insufficiency (POI) [58]. Stromal antigen 3 (STAG3), a meiosis-specific gene expressed only in human testis and ovary, is important in DNA repair [59]. A recent study found two novel in-frame variants of STAG3 that are associated with primary ovarian insufficiency in two sisters from a five-generation consanguineous Han Chinese family [60]. Similar to STAG3 in which clinical evidence associating its mutation to ovarian dysfunction is limited to case studies, helicase for meiosis 1 (HFM1), nucleoporin 107 (NUP107) and synaptonemal complex central element protein 1 (SYCE1) were identified as candidate genes in DNA repair that are implicated in ovarian insufficiency [13, 61-63].

\section{Genes in apoptosis}

The process of apoptosis is highly regulated and plays a crucial role in maintaining a pool of primordial germ cells. During embryonic phase, germ cells that incurred replication errors are eliminated [64]. Furthermore, during each menstrual cycle, there is atresia of follicles other than the dominant follicle. Dysregulation of the process not only leads to a diminished ovarian reserve but also an increased susceptibility to ovarian failure upon exposure to chemotherapy. A study showed that an anti-apoptotic gene bcl-2 knockout transgenic mice have markedly reduced number of primordial germ cells compared to that of control [65]. Other candidate genes involved in the process start to emerge thanks to next generation sequencing [13]. Nanos C2HC-Type Zinc Finger 3 (NANOS3) encodes for an RNA-binding protein that represses apoptosis important in maintaining a healthy pool of primordial germ cells. A missense variant of NANOS3 was identified in a study of Chinese women with primary ovarian insufficiency, and the level of NANOS3 protein was shown to correlate with the number of primordial germ cells [66]. A homozygous mutation of NANOS3 was identified in a different study in two sisters with primary amenorrhea [67]. Another candidate gene, progesterone receptor membrane complex 1 (PGRMC1) which suppresses apoptosis through the 
action of progesterone, was found to be associated with POI $[13,14]$. A study that screened 67 women with idiopathic primary ovarian failure identified a missense mutation of progesterone receptor membrane component 1 (PGRMC1) [68].

\section{Genes in follicular activation and development}

Animal and clinical studies have shown that genetic mutations involved in follicular activation process are associated with primary ovarian failure and likely an increased susceptibility to ovarian failure after chemotherapy [13-15]. FOXO3a is an important suppressor of follicle activation. A study showed that FOXO3a knockout mice had early depletion of ovarian follicles compared to control mice [46]. Screening of 90 women with primary ovarian insufficiency was done by Watkins et al. and rare, potentially causal variants of FOXO3a and FOXO1a were identified [69]. A few years later, another study analyzed FOXO3 mutations in 114 Chinese women with premature ovarian failure and identified six new variants that might cause early follicle depletion [70]. Genetic mutations involved in early follicle development are also implicated in an increased susceptibility to ovarian failure after chemotherapy. Bone morphogenic protein 15 (BMP15) is expressed exclusively in oocytes and was shown to be an important regulator of ovulation rate and ovarian reserve [71]. Small-scale clinical studies in India, Italy and Syria consistently identified genetic variants in women with premature ovarian failure [72-74].

\section{Protective genetic variants against chemotherapy induced ovarian insufficiency}

Potential ovarian protective effects of genetic variants have been reported. A few studies discussed this aspect of genetic associations with POI. For example, a study found a significantly reduced allele frequency of inhibin alpha gene promoter in a group of patients from $\mathrm{New}$ Zealand and Slovenia with POI compared to the control group and suggested a potential protective effect of the allele against POI [75]. A similar study with a larger scale conducted in Italy and Germany suggested a similar protective effect of the rare allele [76]. Another group of studies investigated the protective effect of resveratrol on POI. One such study reported an increased level of MVH,OCT4, SOD2, GPx, and CAT detected after the treatment with resveratrol both in vivo and in vitro [77]. Such protective effect was found to be dose-dependent [78]. This suggests that genetic pathways regulating germline stem cell proliferation and antioxidant enzymes may play a role in protection against development of POI. In addition, a Korean research group reported certain haplotype of microRNA occurred less frequently in patients with POI compared to that in control subjects and further suggested a potential protective effect of these haplotypes [79]. While loss of function of proapoptotic genes has been reported to prevent follicle depletion during chemotherapy, such genetic variants may not preserve germline genome integrity $[34,80]$.

\section{Frequency of genetic variants in primary ovarian insufficiency}

Clinical studies have shown a group of gene variants that appear at a relatively high to medium frequency in patients with POI (Table 2). Many of them are X chromosomal defects and have been shown to be specific to certain ethnic groups. For example, a study conducted in the UK enrolled over two thousand women who experienced menopause before age of 46 to investigate the frequency of premutation in Fragile X Mental Retardation 1 (FMR1) gene characterized by 55-200 CGG repeats [98]. FMR1 premutation was shown to appear at around $2 \%$ frequency in patients presented with POI compared to $0.4 \%$ in the control group. The FMR1 gene is essential for various structures associated with the female reproductive system. It impacts the establishment and the maintenance of cells such as granulosa cells, oocytes, and luteal cells. The gene also plays an indirect role in estrogen secretion by its impact on follicle-stimulating hormone (FSH) levels in the menstrual cycle. Yang et al. found that FMR1 gene expression plays a role in germline stem cells, using Drosophila as a model [99]. Their results showed that the Drosophila FMR1 protein is associated with maintaining oocyte germline stem cells and suppressing differentiation [99]. In humans, the FMR1 premutation is linked to the abnormal levels of FSH secreted from the hypothalamic-pituitary-ovarian axis [100]. Welt and colleagues measured the hormone levels across the menstrual cycle of human females with the FMR 1 premutation. They found that the menstrual cycle was shorter for the FMR1 carriers, especially the follicular phase. Increased levels of FSH was identified during the entire menstrual cycle, and decreased levels of inhibin $\mathrm{B}$, inhibin $\mathrm{A}$, and progesterone were found [100]. It was hypothesized that the decreased levels of inhibin cause a decrease in the negative feedback system, hence an increase in the FSH secretion from the pituitary gland. The imbalance of hormones may cause abnormality in follicular development. The anomalous menstrual cycle associated with FRM1 premutation is therefore a cause of dysregulation of oocyte development.

The frequency of BRCA1 mutation highly associated with POI, was also investigated in the UK in a study with over two thousand women diagnosed with breast cancer between 1991 and 1996 [91]. The study found a frequency of $1.2 \%$ of BRCA1 mutation in the patient group compared to $0.4 \%$ in the control group. Other studies 
Table 2 Genetic Variants Associated with PO

\begin{tabular}{|c|c|c|c|c|c|}
\hline Mechanism & Gene & $\begin{array}{l}\text { Subject } \\
\text { Demographics }\end{array}$ & Subject Sample Size \& Selection Criteria & $\begin{array}{l}\text { Variant } \\
\text { Frequency }\end{array}$ & Reference \\
\hline \multirow[t]{6}{*}{$\begin{array}{l}\text { Follicle } \\
\text { Development }\end{array}$} & NOBOX & $\begin{array}{l}\text { Caucasian, } \\
\text { Senegalese, } \\
\text { Bantu [81] } \\
\text { Caucasian, } \\
\text { African [82] }\end{array}$ & $\begin{array}{l}178 \text { women diagnosed with idiopathic POI and } 362 \text { ethnic-matched } \\
\text { women control [81] } \\
213 \text { women diagnosed with idiopathic POI and } 362 \text { ethnic-matched } \\
\text { women control [82] }\end{array}$ & $\begin{array}{l}6.2 \% \text { in } \mathrm{POI} \\
\text { group } \\
0 \% \text { in control } \\
\text { group [81] } \\
7 \% \text { in POl group } \\
0 \% \text { in control } \\
\text { group [82] }\end{array}$ & {$[81,82]$} \\
\hline & FIGLA & Chinese & $\begin{array}{l}100 \text { women diagnosed with } \mathrm{POI} \text { and } 304 \text { healthy women between } \\
30 \text { and } 62 \text { years old with regular menses and no history of infertility } \\
\text { as control }\end{array}$ & $\begin{array}{l}4 \% \text { in } \mathrm{POI} \text { group } \\
0.3 \% \text { in control } \\
\text { group }\end{array}$ & [83] \\
\hline & $\mathrm{BNC1}$ & Chinese & 82 women diagnosed with $\mathrm{POI}$ and 332 healthy female control & $\begin{array}{l}4 \% \text { in } \mathrm{POI} \text { group } \\
0 \% \text { in control } \\
\text { group }\end{array}$ & [84] \\
\hline & SOHLH1 & China, Serbia & $\begin{array}{l}364 \text { Chinese women and } 197 \text { Serbian women diagnosed with POI } \\
400 \text { Chinese and } 200 \text { Serbian women with regular menses and } \\
\text { normal FSH level as control }\end{array}$ & $\begin{array}{l}2.2 \% \text { in Chinese } \\
\mathrm{POI} \text { group } \\
0.9 \% \text { in Chinese } \\
\text { control group } \\
0 \% \text { in Serbian POI } \\
\text { group } \\
0 \% \text { in Serbian } \\
\text { control group }\end{array}$ & {$[85]$} \\
\hline & $\mathrm{SOHLH} 2$ & China, Serbia & $\begin{array}{l}364 \text { Chinese women and } 197 \text { Serbian women diagnosed with POl; } \\
222 \text { Chinese and } 200 \text { Serbian women with normal menses and } \\
\text { normal FSH level as control }\end{array}$ & $\begin{array}{l}2.2 \% \text { Chinese POI } \\
\text { group } \\
0 \% \text { in Chinese } \\
\text { control group } \\
2 \% \text { in Serbian POI } \\
\text { group } \\
0 \% \text { in Serbian } \\
\text { control group }\end{array}$ & {$[86]$} \\
\hline & $\begin{array}{l}\text { FOXO3A/ } \\
\text { FOXO1A }\end{array}$ & $\begin{array}{l}\text { China, } \\
\text { New Zealand, } \\
\text { Slovenia }\end{array}$ & $\begin{array}{l}114 \text { Chinese patients diagnosed with POI and } 100 \text { control subjects } \\
\text { under the age of } 40 \text { with proven fertility, normal menstrual cycle and } \\
\text { ovarian morphology [87] } \\
30 \text { patients from New Zealand and } 60 \text { patients from Slovenia } \\
\text { diagnosed with POI and } 60 \text { healthy control subjects [69] }\end{array}$ & $\begin{array}{l}13 \% \text { in } \mathrm{POI} \text { group } \\
\text { (FOXO3) } \\
0 \% \text { in control } \\
\text { group (FOXO3) } \\
\text { [87] } \\
2.2 \% \text { in } \mathrm{POI} \\
\text { group (FOXO3A) } \\
0 \% \text { in control } \\
\text { group (FOXO3A) } \\
1.1 \% \text { in POI } \\
\text { group (FOXO1A) } \\
\text { 0\% in control } \\
\text { group (FOXO1A) } \\
\text { [69] }\end{array}$ & {$[69,87]$} \\
\hline \multirow[t]{2}{*}{$\begin{array}{l}\text { Follicle } \\
\text { Development }\end{array}$} & BMP15 & US (Caucasian) & $\begin{array}{l}166 \text { Caucasian women diagnosed with POI and } 211 \text { controls ( } 95 \\
\text { women with menopause beyond } 50 \text { years of age, } 86 \text { women and } 30 \\
\text { men from the general population) }\end{array}$ & $\begin{array}{l}2.1 \% \text { in } \mathrm{POI} \\
\text { group } \\
0 \% \text { in control }\end{array}$ & [88] \\
\hline & $\begin{array}{l}\text { KHDRBS1 } \\
\text { (or } \\
\text { Sam68) }\end{array}$ & Chinese & $\begin{array}{l}215 \text { women diagnosed with POI and } 400 \text { women over age of } 40 \text { not } \\
\text { diagnosed with POI with a history of regular menstrual cycle }\end{array}$ & $\begin{array}{l}0.04 \% \text { in } \mathrm{POI} \\
\text { group } \\
\text { 0\% in control } \\
\text { group }\end{array}$ & [89] \\
\hline $\begin{array}{l}\text { FMR1 } \\
\text { Premutation } \\
\text { (55-200 CGG } \\
\text { repeats) }\end{array}$ & Unknown & UK & $\begin{array}{l}254 \text { women presented with POI and } 1915 \text { controls selected either as } \\
\text { postmenopausal at entry with a menopausal age of } 46 \text { years or older } \\
(74.3 \%) \text { or premenopausal and entered the study at } 46 \text { years or older } \\
(25.7 \%)\end{array}$ & $\begin{array}{l}2 \% \text { in } \mathrm{POI} \text { group } \\
0.4 \% \text { in control } \\
\text { group }\end{array}$ & [90] \\
\hline \multirow[t]{2}{*}{$\begin{array}{l}\text { DNA } \\
\text { Damage Repair }\end{array}$} & BRCA1 & UK & $\begin{array}{l}2028 \text { women diagnosed with breast cancer before age of } 55 \\
\text { between } 1991 \text { and } 1996 \\
\text { prevalence calculated based on a mathematical model }\end{array}$ & $\begin{array}{l}1.2 \% \text { in cancer } \\
\text { group; } \\
0.09 \% \text { in general } \\
\text { population }\end{array}$ & [91] \\
\hline & MCM8/9 & US & $\begin{array}{l}155 \text { women diagnosed with } \mathrm{POI} \\
\text { Control group data from public database such as exome variant } \\
\text { server }\end{array}$ & $\begin{array}{l}2 \% \text { in } \mathrm{POl} \text { group } \\
\text { (MCM8) } \\
0 \% \text { in control } \\
\text { group (MCM8) }\end{array}$ & [92] \\
\hline
\end{tabular}


Table 2 Genetic Variants Associated with POI (Continued)

\begin{tabular}{|c|c|c|c|c|c|}
\hline Mechanism & Gene & $\begin{array}{l}\text { Subject } \\
\text { Demographics }\end{array}$ & Subject Sample Size \& Selection Criteria & $\begin{array}{l}\text { Variant } \\
\text { Frequency }\end{array}$ & Reference \\
\hline & & & & $\begin{array}{l}5 \% \text { in } \mathrm{POI} \text { group } \\
\text { (MCM9) } \\
0 \% \text { in control } \\
\text { group (MCM9) }\end{array}$ & \\
\hline & FANCM & Chinese & $\begin{array}{l}200 \text { patients diagnosed with POI and } 200 \text { age-matched women with } \\
\text { regular menses an normal FSH level as control }\end{array}$ & $\begin{array}{l}0.4 \% \text { in } \mathrm{POI} \\
\text { group } \\
0 \% \text { in control } \\
\text { group }\end{array}$ & [93] \\
\hline \multirow[t]{2}{*}{$\begin{array}{l}\text { Apoptosis } \\
\text { Regulation }\end{array}$} & NANOS3 & $\begin{array}{l}\text { Chinese, } \\
\text { Caucasian, } \\
\text { Brazilian }\end{array}$ & $\begin{array}{l}80 \text { Chinese women and } 88 \text { Caucasian women diagnosed with POI } \\
\text { and } 63 \text { healthy Chinese and } 63 \text { healthy Caucasian control subjects } \\
\text { [94] } \\
30 \text { Brazilian women diagnosed with POI and } 185 \text { women with normal } \\
\text { fertility as control [95] }\end{array}$ & $\begin{array}{l}0.14 \% \text { in Chinese } \\
\mathrm{POI} \text { group } \\
0.09 \% \text { in Chinese } \\
\text { control group } \\
0.09 \% \text { in } \\
\text { Caucasian POI } \\
\text { group } \\
0.03 \% \text { in } \\
\text { Caucasian control } \\
\text { group [94] } \\
0 \% \text { in POI group } \\
0 \% \text { in control } \\
\text { group [95] }\end{array}$ & {$[94,95]$} \\
\hline & PGRMC1 & China & $\begin{array}{l}196 \text { nulligravida women diagnosed with POI without family history of } \\
\text { POI or X chromosome abnormalities and } 200 \text { healthy women with } \\
\text { regular menstrual cycle and no known history of infertility before age } \\
\text { of } 40 \text { years }\end{array}$ & $\begin{array}{l}0.51 \% \text { in } \mathrm{POI} \\
\text { group } \\
0 \% \text { in control } \\
\text { group }\end{array}$ & [96] \\
\hline HFM1 & Meiosis & Chinese & $\begin{array}{l}69 \text { women diagnosed with POI and } 316 \text { controls matched for ethnic } \\
\text { background, sex and age }\end{array}$ & $\begin{array}{l}2.9 \% \text { in } \mathrm{POI} \\
\text { group } \\
\text { 0\% in control } \\
\text { group }\end{array}$ & [97] \\
\hline
\end{tabular}

${ }^{*} \mathrm{POI}$ Primary ovarian insufficiency characterized by onset of menopause before age of 40 with elevated FSH level

conducted so far are small-scale that enrolled patients in the low hundreds. A few genetic variants such as MCM8/9, BMP15, FOXO3 and SOHLH1 have been found to occur around $2 \%$ frequency in POI patients compared to close to $0 \%$ in control groups (Table 2). Genetic variants such as NANOS3, FOXO1A and PGMRC1 have been found to appear at frequency lower than $1.1 \%$ in various ethnic groups. Autosomal defects underlying a group of complex diseases ranging from metabolism to autoimmune disorders, in rare occasions, are associated with POI.

\section{Clinical considerations}

\section{Candidate genetic markers}

There are several advantages of using genetic markers complementary to the current ovarian reserve markers of $\mathrm{AMH}$, antral follicle count and day $3 \mathrm{FSH}$ as predictors of preservation of fertility after chemotherapy. Genetic markers will help identify disturbances in upstream pathways leading to high risk of ovarian failure that may be missed by molecular markers. An ideal genetic marker should have a high-frequency variant specific to patients who experience ovarian failure after chemotherapy. In addition, the basic science of the associated genetic pathways should be investigated and understood.
Genes upstream in these pathways could be selected for additional insights. Based on our literature review, such candidate genes associated with POI and chemotherapyinduced ovarian damage mechanisms have been identified (Table 2). The difference between the prevalence of the gene variants in the POI patients and in the healthy patients affect the positive and negative predictive values of the genetic markers. FMR1 and BRCA 1 testing are performed routinely in genetic clinics. Large-scale studies of FMR1 premutations and BRCA1 mutations revealed their prevalence to be 2 and $1.2 \%$ in the POI group and 0.9 and $0.04 \%$ in the healthy group, respectively. Frequency of other candidate gene marker variants has been derived from studies involving around 100 subjects. The frequencies of variants range from 2 to $13 \%$ in the POI population and consistently stay around $0 \%$ in the control group (Table 2). Large-scale and multi-racial studies still need to be performed to further elucidate the prevalence of these genes in the POI and the control populations. Nevertheless, the current clinical studies provide support for consideration of use of genetic markers in the clinics.

Predictive genetic markers should have a high prevalence in the POI patients and a low prevalence in the healthy population. The biological basis for selecting the 
genetic markers needs to be supported by basic science. Based on these criteria, we propose a research screening algorithm to understand different levels of risk of loss of ovarian reserve among patients about to undergo chemotherapy (Fig. 2). The testing proposed will begin with screening of higher frequency pathogenic variants and progress to screening of lower frequency variants. The level of risk of each patient will be assessed based on panel results in addition to the other tests results such as day-3 serum FSH and AMH levels and antral follicle count. In the long run, a one-step 7-gene panel including FMR1 and BRCA1 with five other higher frequency variants may be developed and performed routinely to assess risk for every patient (Fig. 3).

\section{Applications of next generation sequencing (NGS) in ovarian reserve testing}

First-generation DNA sequencing using chainterminator inhibitors has been widely used in diagnostic testing for the past 30 years since its invention in 1977 [101]. NGS has more recently begun to replace it in genetic testing due to its high speed and throughput [13, 102, 103]. Applications of NGS include targeted gene panel, whole exome sequencing (WES) and whole genome sequencing (WGS). These applications have contributed to the discovery of genes associated POI. Genetic etiology of POI may be monogenetic or polygenetic and can be broadly characterized in two categories: 1) genes and loci associated with POI and 2) genes and loci associated with disorders where ovarian insufficiency may be one of the symptoms $[13,15,104]$. Applications of NGS will not only continue to contribute to the discovery of genes associated with POI but also facilitate the ovarian reserve testing for patients with cancer prior to chemotherapy (Fig. 4). For example, targeted gene panel testing allows for a relatively quick and cost-effective way of screening of multiple genes associated with POI and provides more flexibility than singlegene testing. WES screens for protein-coding regions, approximately $1-2 \%$ of the genome and typically identifies 30,000 to 40,000 genetic variants that differ from the reference genome per person. WGS screens the entire genome including the non-coding regions and typically identifies 3-4 million variants per person [105, 106]. While a genome can now be sequenced within a day, the data sets generated by WES and WGS are high dimensional and complex in structure and requires continuous development of computing tools, platforms and guidelines around data security and infrastructure to reduce the cost of obtaining a complete disease profile from the raw data [107-110]. Despite the challenges, WES and WGS may be considered in cases where no diagnosis is obtained from targeted gene panel testing. NGS applications are the future of genetic diagnosis of patients who

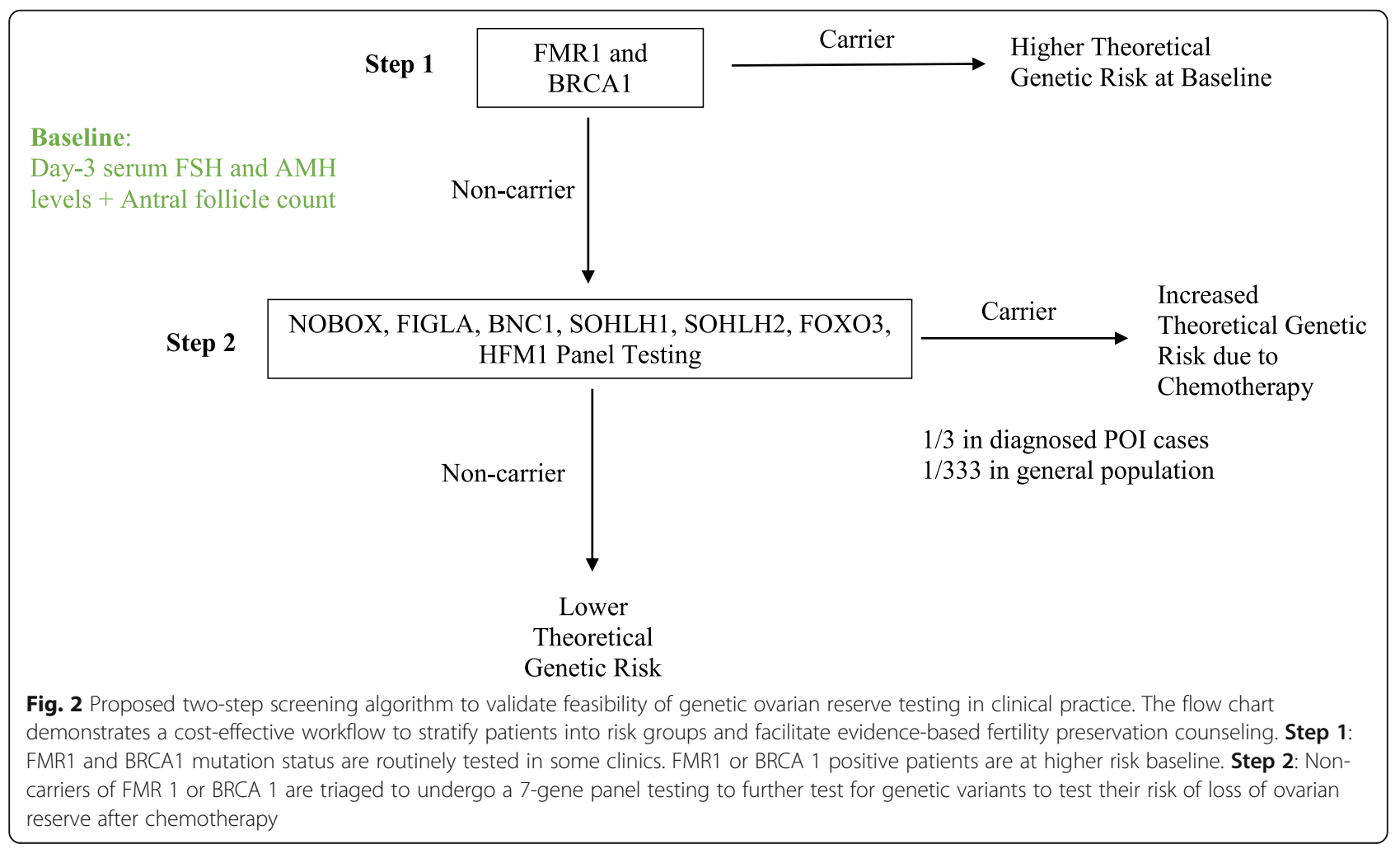




\begin{tabular}{|l} 
Step 1 \\
$\begin{array}{c}\text { FMR1, BRCA1, NOBOX, FIGLA, BNC1, FOXO3, } \\
\text { HFM1 Panel Testing }\end{array}$
\end{tabular}

are susceptible to loss of ovarian reserve upon exposure to chemotherapy. We propose an initial adoption of targeted gene panel screening discussed below due to its lower cost and higher sequencing depth compared to WES and WGS. As the prices for WES and WGS decrease over time, they will be fully integrated into the clinical workflow and provide physicians with more diagnostic options.

\section{Screening}

Obtaining a comprehensive picture of a patient's genetic background enables more informative, evidence-based fertility preservation planning. In the long run, it is also likely to bring a positive economic impact on the cost of fertility preservation in female cancer patients. The average cost for a female cancer patient to preserve her fertility through oocyte or embryo cryopreservation was found to be $\$ 8655$

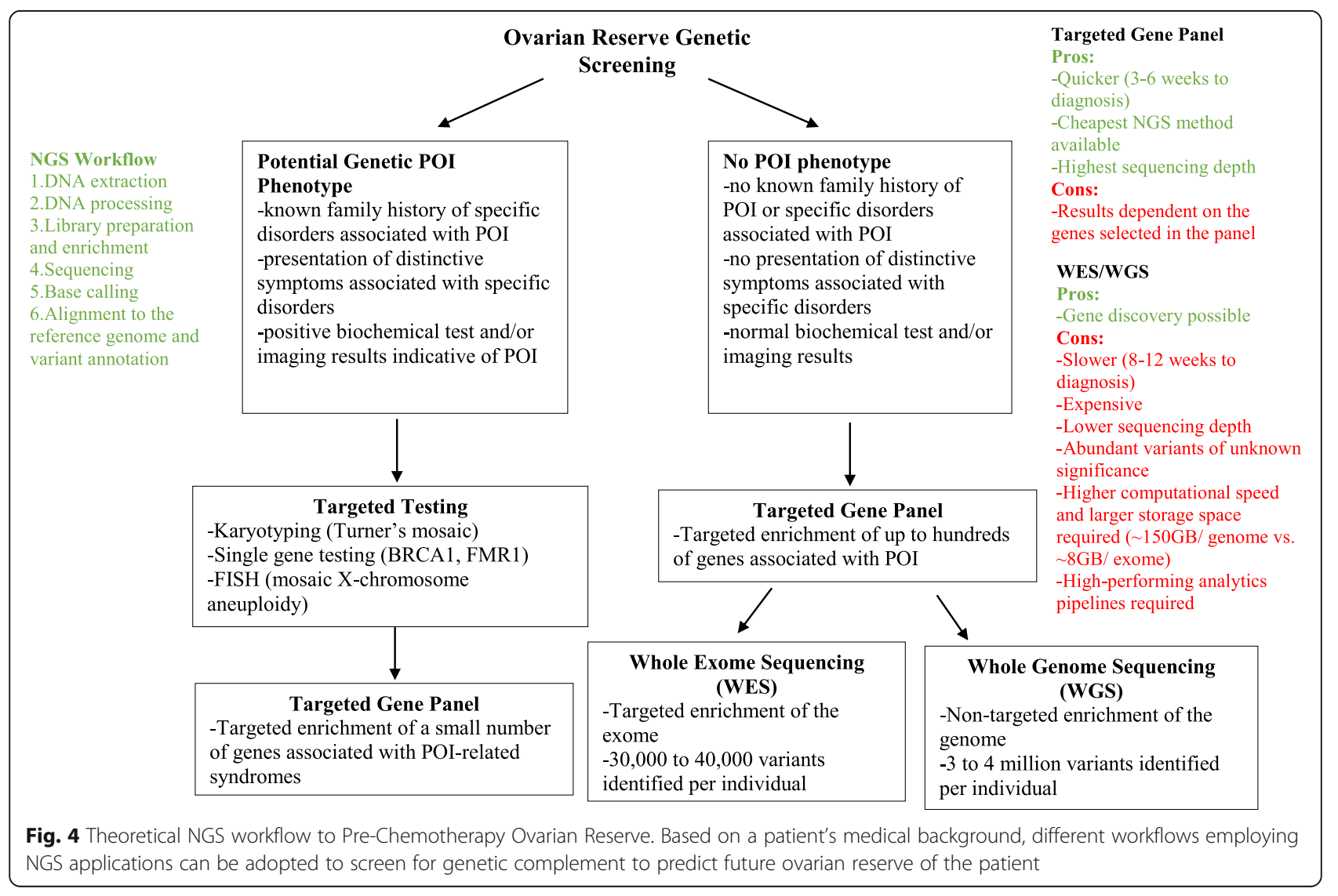


by a study that surveyed 154 reproductive clinics in the US [111]. A recent study reported the cost of NGS infertility gene panel consisting of 87 genes to be $\$ 599$ [112]. A 49-gene panel for genomic analysis of solid tumors was reported to cost around $\$ 449$ [113]. The cost of gene panels consisting of less than 10 genes can be reasonably controlled to within $\$ 200$ to $\$ 300$ based on these results. In fact, multigene panel testing has recently been evaluated for its cost-effectiveness for all patients with breast cancer and one study in Norway found that a 7-gene panel with 5 non-BRCA genes was the optimal strategy with the highest incremental cost-effectiveness ratio [114, 115]. Given the current trend of moving towards precision reproductive medicine, commercial and institutional genetic panels for infertility risk assessment have started to emerge [116]. Performing multigene panel testing on patients indicated for chemotherapy can help clinicians stratify patients into risk groups and in the long run, provide targeted therapeutics for each patient. Due to the ethnic-group specific nature of current studies, we propose a trial 7-gene panel encompassing variants that appear at a high frequency specific to the ethnic group of the patient. For example, for a Han Chinese patient, a panel encompassing newborn ovary homeobox protein (NOBOX), folliculogenesis specific BHLH transcription factor (FIGLA), basonuclin 1 (BNC1), spermatogenesis and oogenesis specific basic helix-loop -helix 1 (SOHLH1), SOHLH2, FOXO3 and HFM1 may be ordered to identify patients susceptible to ovarian failure after chemotherapy that might not be apparent otherwise (Fig. 2). The prevalence of POI in the general population is 1\% [117]. Assuming that having any one of the seven genetic variants is a mutually exclusive event, approximately 1 in 333 patients from the general population will be screened positive for one of the variants. Currently, the turnaround time for a multigene panel is between 4 and 6 weeks. For patients about to undergo chemotherapy, waiting for panel results could delay timesensitive treatments. With advancement of technology, we expect the turnaround time to be shortened to between 3 and 4 days before multigene panel could be integrated into clinical onco-fertility practice. Furthermore, in the long run, a comprehensive panel testing encompassing all the genes known to be associated with POI should be examined (Tables 2, 3). Variants should be grouped according to their underlying mechanism of pathology. Carriers with more groups of variants may be at higher risk of developing ovarian failure compared to carriers with fewer groups of variants. Disease-inducing potential of each variant should be evaluated.

\section{Higher theoretical genetic risk at baseline}

Certain genetic mutations such as FMR1 premutation and BRCA1 mutation have been shown to increase not only the risk of developing POI but also the risk of developing other pathologies. These genes should be screened routinely. For example, FMR1 premutation has been identified in 0.8 to $7.5 \%$ of cases of sporadic POI and up to $13 \%$ of cases of familial POI [149]. Prevalence of POI in carriers of FMR1 premutation has historically been shown to be between 13 to 26\% [150, 151]. Another study, however, found it to be around 2\% [98]. An accurate prevalence needs to be established through large-scale, population-specific studies. FMR1 premutation is also known to cause associated tremor/ataxia syndrome and a variety of phenotypes ranging from neuropathy to immune mediated disorder [152]. Similarly, BRCA1 mutation has recently been associated with POI but has long been screened at clinics as a marker of risk of developing breast cancer [153]. Carriers of FMR1 premutation or BRCA1 mutation are at high risk of developing ovarian failure regardless of chemotherapy. Prior to chemotherapy, carriers with age over 40 may have already presented with POI or other phenotypes. Prompt fertility preservation is encouraged for patients who wish to conceive in the future. Younger patients are likely to be asymptomatic and need to be identified through screening. Their risk of eventually developing ovarian failure and a potentially accelerated progression due to chemotherapy should be communicated. Fertility preservation in these patients should be discussed without delay.

\section{Increased risk due to chemotherapy}

Patients that screened negative for FMR1 and BRCA1 mutations requires further clinical investigation. Recent sequencing studies have identified several genetic variants such as NOBOX, FIGLA, SOHLH1, SOHLH2, FOXO3 and HFM1 that appear in high frequency in patients with POI. These genes have also been shown to be implicated in mechanism of ovarian failure. For example, NOBOX, FIGLA, SOHLH1, SOHLH2 and FOXO3 were found to be important in follicle development. HFM1 was found to be implicated in progression of meiosis. Screening of variants of the seven genes should be considered in patients who wish to conceive. Carriers of any one of the variants may be susceptible to exaggerated ovarian damage due to chemotherapy. Genetic profile of the variants complementary to medical history provides additional information to help patients gauge their risk of developing ovarian failure after chemotherapy and plan with clinicians about fertility preservation accordingly. In the future, a more comprehensive gene panel encompassing up to hundreds of genes may be tested to stratify patients in this group at a higher resolution. For example, carriers of both higher frequency and lower frequency variants may be at a different level of risk compared to carriers of higher frequency variants alone. As the penetrance and pathogenicity of each variant is 
Table 3 Emerging Genes Associated with POI

\begin{tabular}{|c|c|c|}
\hline Mechanism & Gene & Animal Study \\
\hline $\begin{array}{l}\text { Cell-cycle progression; } \\
\text { DNA damage } \\
\text { response }\end{array}$ & $\begin{array}{l}\text { NUP- } \\
107\end{array}$ & $\begin{array}{l}\text { Knockdown of NUP107 expression led to decreased } \\
\text { expression of genes related to estrogen synthesis and } \\
\text { receptors on granulosa cells which interferes their } \\
\text { sensitivity to FSH [118] }\end{array}$ \\
\hline $\begin{array}{l}\text { Regulation of } \\
\text { ovulation rate; oocyte } \\
\text { functional } \\
\text { competence }\end{array}$ & BMPR2 & $\begin{array}{l}\text { A BMPR2 missense mutation led to aggregates localized } \\
\text { at the endoplasmic reticulum in Chinese hamster ovary } \\
\text { cell }[120] \\
\text { BMPR2 is involved in signal transduction between } \\
\text { oocytes and somatic cells }[121,122]\end{array}$ \\
\hline Meiosis & SYCE1 & $\begin{array}{l}\text { SYCE1 homozygous mutant mice failed to have } \\
\text { offspring after } 3 \text { months and no follicles or oocytes were } \\
\text { observed. Wildtype and heterozygous mutant females } \\
\text { were normal [123] }\end{array}$ \\
\hline
\end{tabular}

\section{Human Study}

A missense mutation of NUP107 was identified in two

sisters with hypergonadotropic hypogonadism [119]

BMPR2 is implicated in folliculogenesis and human ovarian functions [120]

A homozygous missense mutation was identified in two sisters with primary amenorrhea born to a consanguineous parents [63]

SYCE1 mutation was found to be underlie an autosomal recessive pattern of POI [124]

STAG3 STAG3 deficient female mice were found to be sterile with their fetal oocytes arrested at early prophase I. Their oocytes were found to be depleted at 1 week of age [125]

A truncating mutation was identified in two sisters with primary amenorrhea from a consanguineous Lebanese family [126]

Two nonsense mutations were identified in two Caucasian sisters presented with POI [127] Two homozygous germline truncation mutations were identified in two sisters diagnosed with POI from a consanguineous Han Chinese family [128]

MSH4 MSH4 knockout mice presented with meiotic failure and infertility. Many oogonia had been lost at 2-day postnatal detection. Ovaries were found to be small and contain few oocytes at 4 weeks [129]

MSH5 MSH5 knockout mice was infertile and found to have a markedly reduced size of ovary with no developing follicles. At 2 months of age, no germ cells were found in these mice [131]

DMC1 DMC1 knockout mice presented with aborted oogenesis in embryos and no germ cells were found in adult mice ovary with a markedly reduced size of ovary. At 8-week postnatal evaluation, no follicles were found at any developmental stage [132]

WDR62 WDR62 knockout mice exhibited meiotic initiation defects [134]

Intercellular communication

GJA4 Connexin-37 is encoded by GJA4 gene. Connexin-37 deficient mice was found to lack mature follicles. They also failed to ovulate and developed numerous inappropriate corpora lutea [135]

mRNA transcription; Cell growth and differentiation

POLR2C POLR2C haploinsufficiency was found to disrupt rapid mRNA synthesis required during germ cell proliferation and oocyte maturation process in mice $[137,138]$

$\mathrm{POLR3H}$ Mice with the same missense mutation in POLR3H in patients with $\mathrm{POI}$ exhibited impaired reproductive function [140]

Germ cell development

MRPS22 Knockdown of MRPS22 in germ cells led to female sterility in drosophila [141]

NOTCH2 NOTCH2 knockout mice exhibited defective follicle development [142]

Autophagy

ATG7/9 Germ-cell specific ATG7-knockout mice exhibited oocyte over-loss during neonatal period [144]

Apoptosis; Cell cycle TP63 TP63 protects female mice germline integrity during progression

Homologous

DNA repair
A homozygous donor splice site mutation was found to cause POI [130]

A homozygous missense mutation was identified in two Chinese sisters with POI [131]

A homozygous missense mutation was identified in a Chinese consanguineous family with POI phenotype [133]

Two missense mutations were detected in two patients with POI [134]

A mutation was identified in 2 Caucasian patient with POI [136]

A nonsense mutation was identified in a family with a dominant inheritance pattern of POI [139]

A homozygous missense mutation was identified in two unrelated families with idiopathic POI [140]

Two homozygous missense mutations were identified in four females from two independent consanguineous families [141]

Two missense mutations were identified in patients diagnosed with POI [143]

Two heterozygous missense mutations were identified in two patients diagnosed with POI [145]

A homozygous nonsense mutation was identified in two daughters of consanguineous double first cousin parents of Arab ancestry, both diagnosed with POI [148] 
better understood, such a comprehensive gene panel will provide detailed genetic profiles to guide fertility preservation practices.

\section{Lower theoretical genetic risk}

Patients without presentation or familial history of POI that screened negative for FMR1, BRCA1 and the seven genes mentioned above may have a lower theoretical probability of developing ovarian failure after chemotherapy, given our current understanding. Screening of rare genes associated with POI might be considered, if given sufficient clinical suspicion of increased risk.

\section{Future studies}

The mechanism of ovarian damage due to chemotherapy is still not completely understood. Animal studies provided evidence that support germ and stromal cell apoptosis and/or accelerated follicle activation as possible mechanisms. There has yet to be conclusive results elucidating to what extent each mechanism gives rise to human clinical manifestation of ovarian failure. Future animal studies include co-immunohistological staining using markers of apoptosis and follicle activation on ovarian tissue after chemotherapy. Additional or alternative mechanisms might also arise through further investigation. Furthermore, human studies are essential to understanding the mechanism of damage. For example, biopsies of ovarian tissue in patients who experience ovarian failure after chemotherapy and need to undergo surgery may be collected and stained for markers of apoptosis and follicle activation. Staining results may further be correlated with genetic profile to validate the screening process proposed above. We expect patients with genetic variants implicated in DNA repair such as BRCA1 and MCM8/9 to present with strong markers for apoptosis and with those implicated in follicle activation such as FOXO3, BMP15 and SOHLH1 to present with strong markers for follicle activation. In addition, a patient's genetic profile should be evaluated in conjunction with day-3 serum FSH and AMH levels as well as antral follicle count to understand if any correlations between genetic test results and these other test results exists.

Deep genetic sequencing should be performed on women with idiopathic POI to continue to uncover associated genetic variants at high resolution. As these genetic variants emerge, large scale, ethnic-group specific screening studies should be performed to investigate the frequency of these variants. Current studies are largely limited to about 100 patients and to certain ethnic groups (Table 2). These preliminary studies showed that some genetic variants are specific to ethnic groups. In addition, the frequency of individual variants in the control group in these studies are close to $0 \%$. If future studies were to confirm these findings, a patientcentered variant screening program rather than a onefor-all routine screening proposed above would need to be established. Alternatively, specific patient groups may be selected with a recommendation of undergoing a genetic panel test.

\section{Conclusion}

Certain chemotherapeutic agents have been documented to induce a high rate of ovarian failure in patients (Table 1 ). Yet, the effects of the ovarian reserve by the agents vary from patient to patient. This makes counseling and planning for fertility preservation challenging. Ovarian reserve testing using clinical markers predicts ovarian function after chemotherapy based on a patient's baseline ovarian reserve. But some patients with high baseline ovarian reserve have poor outcomes after treatment. This discrepancy points to the need for a more predictive marker for a patient's reproductive potential after chemotherapy. Genetic markers hold the promise to fulfil this need. As the mechanism of chemotherapyinduced ovarian damage continues to be investigated, genetic variants underlying these pathways may reliably predict reproductive potential based on basic mechanisms. Variants that appear in high frequency can be incorporated into routine screening in addition to molecular markers to help patients assess their risk.

\section{Abbreviations \\ KO: Knockout; WT: Wildtype; AMH: Anti-Mullerian hormone; PUMA: P53- upregulated modulator of apoptosis; PARP: Poly-ADP ribose polymerase; PI3K: Phosphatidylinositol 3-kinase; PTEN: Phosphatase and tensin homolog; FOXO3a: Forkhead box 03; TSC1,2: Tuberous sclerosis 1, 2; \\ MCM8,9: Minichromosome maintenance 8, 9 homologous recombination repair factor; POI: Primary ovarian insufficiency; STAG3: Stromal antigen 3; HFM1: Helicase for meiosis 1; NUP107: Nucleoporin 107; \\ SYCE1: Synaptonemal complex central element protein 1; NANOS3: Nanos $\mathrm{C} 2 \mathrm{H} 2$-type zinc finger 3; PGRMC1: Progesterone receptor membrane component 1; BMP15: Bone morphogenic protein 15; FMR1: Fragile X mental retardation 1; FSH: Follicle-stimulating hormone; NGS: Next-generation sequencing; WES: Whole-exome sequencing; WGS: Whole-genome sequencing; NOBOX: Newborn ovary homeobox; FIGLA: Folliculogenesis specific BHLH transcription factor; BNC1: Basonuclin 1; \\ SOHLH1,2: Spermatogenesis and oogenesis specific basic helix-loop-helix 1}

\section{Acknowledgements}

The authors thank Veslemoy L. Moberg for useful initial discussions on the topic of this paper.

\section{Authors' contributions}

$J Y$ and BS contributed equally to the conception of idea, writing and editing of the final version of the manuscript. The authors read and approved the final manuscript.

\section{Funding}

MC Chang Memorial Award of the Worcester Foundation, Worcester, MA. 


\section{Declarations}

\section{Ethics approval and consent to participate}

Not applicable.

\section{Consent for publication}

Not applicable.

\section{Competing interests}

The authors declare that they have no competing interests.

\section{Author details}

${ }^{1}$ Sackler School of Medicine, New York State/American Program of Tel Aviv University, Tel Aviv University, Ramat Aviv 69978, Tel Aviv, Israel. ${ }^{2}$ Division of Reproductive Endocrinology and Infertility, Department of Obstetrics \& Gynecology, University of Massachusetts Medical School, UMass Memorial Medical Center, 119 Belmont Street, Worcester, MA 01605, USA

Received: 22 January 2021 Accepted: 19 May 2021

Published online: 30 June 2021

\section{References}

1. Siegel RL, Miller KD, Jemal A. Cancer statistics, 2020. CA Cancer J Clin. 2020; 70(1):7-30. https://doi.org/10.3322/caac.21590.

2. Sonigo C, Beau I, Binart N, Grynberg M. The impact of chemotherapy on the ovaries: molecular aspects and the prevention of ovarian damage. Int J Mol Sci. 2019;20. https://doi.org/10.3390/ijms20215342.

3. International Indicators: Total Fertility Rate - PRB. https://www.prb.org/ international/indicator/fertility/map/country.

4. Tiong $\mathrm{V}$, Rozita AM, Taib NA, Yip $\mathrm{CH}, \mathrm{Ng} \mathrm{CH}$. Incidence of chemotherapyinduced ovarian failure in premenopausal women undergoing chemotherapy for breast cancer. World J Surg. 2014;38(9):2288-96. https:// doi.org/10.1007/s00268-014-2542-y.

5. Ye M, Yeh J, Kosteria I, Li L. Progress in fertility preservation strategies in turner syndrome. Frontiers in Medicine. 2020;7. https://doi.org/10.3389/ fmed.2020.00003.

6. Han HS, Ro J, Lee KS, Nam BH, Seo JA, Lee DH, et al. Analysis of chemotherapy-induced amenorrhea rates by three different anthracycline and taxane containing regimens for early breast cancer. Breast Cancer Res Treat. 2009;115(2):335-42. https://doi.org/10.1007/s10549-008-0071-9.

7. Pfeifer S, Butts S, Dumesic D, Fossum G, Giudice L, Gracia C, et al. Testing and interpreting measures of ovarian reserve: a committee opinion. Fertil Steril. 2015;103:e9-17. https://doi.org/10.1016/j.fertnstert.2014.12.093.

8. Yeh J, Kim BS, Liang YJ, Peresie J. Baseline and stimulated serum inhibin levels as biomarkers of cisplatin-induced ovarian damage in female rats. Am J Obstet Gynecol. 2008;198:82.e1-6.

9. Yeh J, Kim B, Liang YJ, Peresie J. Müllerian inhibiting substance as a novel biomarker of cisplatin-induced ovarian damage. Biochem Biophys Res Commun. 2006;348(2):337-44. https://doi.org/10.1016/j.bbrc.2006.06.195.

10. Yeh J, Kim B, Peresie J, Liang YJ, Arroyo A. Serum and ovarian Müllerian inhibiting substance, and their decline in reproductive aging. Fertil Steril. 2007;87:1227-30. https://doi.org/10.1016/j.fertnstert.2006.11.011.

11. Yeh J, Kim B. Increasing blunting of inhibin responses to dynamic ovarian challenge is associated with reproductive aging in the rat. Reprod Sci. 2007; 14(1):10-9. https://doi.org/10.1177/1933719106298186.

12. Yeh J. Use of gene markers as a novel method to predict loss of ovarian function due to breast Cancer treatment. Curr Women s Heal Rev. 2020; 16(2):85-6. https://doi.org/10.2174/157340481602200313100543.

13. Malheiros França M, Mendonca BB. Genetics of primary ovarian insufficiency in the next-generation sequencing era. J Endocr Soc. 2020;4:1-16.

14. Tucker EJ, Grover SR, Bachelot A, Touraine P, Sinclair AH. Premature ovarian insufficiency: new perspectives on genetic cause and phenotypic Spectrum. Endocr Rev. 2016;37:609-35. https://doi.org/10.1210/er.2016-1047.

15. Rossetti R, Ferrari I, Bonomi M, Persani L. Genetics of primary ovarian insufficiency. Clin Genet. 2017;91:183-98. https://doi.org/10.1111/cge.12921.

16. Oktem O, Oktay K. Quantitative assessment of the impact of chemotherapy on ovarian follicle reserve and stromal function. Cancer. 2007;110(10):22229. https://doi.org/10.1002/cncr.23071.

17. Ovarian Damage From Chemotherapy and Current Approaches to Its Protection - PubMed. https://pubmed.ncbi.nlm.nih.gov/31600388/. Accessed 21 Jun 2020.
18. Miller JJ, Williams GF, Leissring JC. Multiple late complications of therapy with cyclophosphamide, including ovarian destruction. Am J Med. 1971; 50(4):530-5. https://doi.org/10.1016/0002-9343(71)90341-X.

19. H K, T W, Y N , TI, Y A. Cyclophosphamide-induced Ovarian Failure and Its Therapeutic Significance in Patients With Breast Cancer. Cancer. 1977:39 doi: 10.1002/1097-0142(197704)39:4<1403::AID-CNCR2820390408>3.0.CO;2-8.

20. Yeh J, Kim BS, Peresie J. Reproductive toxic effects of cisplatin and its modulation by the antioxidant sodium 2-mercaptoethanesulfonate (Mesna) in female rats. Reprod Biol Insights. 2011;4:17-27.

21. Yeh J, Kim BS, Peresie J. Protection against cisplatin-induced ovarian damage by the antioxidant sodium 2-mercaptoethanesulfonate (mesna) in female rats. Am J Obstet Gynecol. 2008;198:463.e1-7. https://doi.org/10.101 6/j.ajog.2007.12.027.

22. Yeh J, Beom SK, Peresie J, Page C. Declines in levels of Hyperpolarizationactivated Cation (HCN) channels in the rat ovary after cisplatin exposure. Reprod Sci. 2009;16:986-94. https://doi.org/10.1177/1933719109339217.

23. Yeh J, Kim BS, Liang YJ, Peresie J. Gonadotropin stimulation as a challenge to calibrate cisplatin induced ovarian damage in the female rat. Reprod Toxicol. 2009;28(4):556-62. https://doi.org/10.1016/j.reprotox.2009.08.003.

24. Perez Gl, Knudson CM, Leykin L, Korsmeyer SJ, Tilly JL. Apoptosis-associated signaling pathways are required for chemotherapy- mediated female germ cell destruction. Nat Med. 1997;3(11):1228-32. https://doi.org/10.1038/nm11 97-1228.

25. Kim YY, Kim WO, Liu HC, Rosenwaks Z, Kim JW, Ku SY. Effects of paclitaxel and cisplatin on in vitro ovarian follicle development. Arch Med Sci. 2019; 15(6):1510-9. https://doi.org/10.5114/aoms.2019.81730.

26. Mikuła-Pietrasik J, Witucka A, Pakuła M, Uruski P, Begier-Krasińska B, Niklas A et al. Comprehensive review on how platinum- and taxane-based chemotherapy of ovarian cancer affects biology of normal cells. Cell Mol Life Sci. 2019:76(4):681-97. https://doi.org/10.1007/s00018-018-2954-1.

27. Bar-Joseph H, Ben-Aharon I, Rizel S, Stemmer SM, Tzabari M, Shalgi R. Doxorubicin-induced apoptosis in germinal vesicle (GV) oocytes. Reprod Toxicol. 2010;30:566-72.

28. Wang Y, Liu M, Johnson SB, Yuan G, Arriba AK, Zubizarreta ME, et al. Doxorubicin obliterates mouse ovarian reserve through both primordial follicle atresia and overactivation. Toxicol Appl Pharmacol. 2019;381.

29. Chang EM, Lim E, Yoon S, Jeong K, Bae S, Lee DR, et al. Cisplatin induces Overactivation of the dormant primordial follicle through PTEN/AKT/ FOXO3a pathway which leads to loss of ovarian Reserve in Mice. PLoS One. 2015;10:e0144245. https://doi.org/10.1371/journal.pone.0144245.

30. Hastie R, Lim E, Sluka P, Campbell L, Horne AW, Ellett L, et al. Vinorelbine potently induces placental cell death, does not harm fertility and is a potential treatment for ectopic pregnancy. EBioMedicine. 2018;29:166-76. https://doi.org/10.1016/j.ebiom.2018.01.041.

31. Levi M, Hasky N, Stemmer SM, Shalgi R, Ben-Aharon I. Anti-Müllerian hormone is a marker for chemotherapy-induced testicular toxicity. Endocrinology. 2015;156(10):3818-27. https://doi.org/10.1210/en.2015-1310.

32. Yuksel A, Bildik G, Senbabaoglu F, Akin N, Arvas M, Unal F, et al. The magnitude of gonadotoxicity of chemotherapy drugs on ovarian follicles and granulosa cells varies depending upon the category of the drugs and the type of granulosa cells. Hum Reprod. 2015;30:2926-35. https://doi.org/1 0.1093/humrep/dev256.

33. Soleimani R, Heytens E, Darzynkiewicz Z, Oktay K. Mechanisms of chemotherapy-induced human ovarian aging: double strand DNA breaks and microvascular compromise, Aging (Albany NY). 2011;3:782-93. https:// doi.org/10.18632/aging.100363.

34. Nguyen QN, Zerafa N, Liew SH, Morgan FH, Strasser A, Scott CL, et al. Loss of PUMA protects the ovarian reserve during DNA-damaging chemotherapy and preserves fertility. Cell Death Dis. 2018;9(6):1-12. https://doi.org/10.103 8/s41419-018-0633-7.

35. Khan SM, Oliver RH, Yeh J. Epidermal growth factor receptor inhibition by tyrphostin 51 induces apoptosis in luteinized granulosa cells. J Clin Endocrinol Metab. 2005;90:469-73. https://doi.org/10.1210/jc.2004-0454.

36. Khan SM, Oliver RH, Dauffenbach LM, Yeh J. Depletion of Raf-1 protooncogene by geldanamycin causes apoptosis in human luteinized granulosa cells. Fertil Steril. 2000;74(2):359-65. https://doi.org/10.1016/S00150282(00)00633-6.

37. Oliver RH, Khan SM, Leung BS, Yeh J. Induction of apoptosis in luteinized granulosa cells by the MAP kinase kinase (MEK) inhibitor PD98059. Biochem Biophys Res Commun. 1999;263(1):143-8. https://doi.org/10.1006/bbrc.1 999.1301. 
38. Izawa M, Nguyen PH, Kim HH, Yeh J. Expression of the apoptosis-related genes, caspase-1, caspase-3, DNA fragmentation factor, and apoptotic protease activating factor-1, in human granulosa cells. Fertil Steril. 1998; 70(3):549-52. https://doi.org/10.1016/S0015-0282(98)00194-0.

39. Khan SM, Dauffenbach LM, Yeh J. Mitochondria and caspases in induced apoptosis in human luteinized granulosa cells. Biochem Biophys Res Commun. 2000;269(2):542-5. https://doi.org/10.1006/bbrc.2000.2321.

40. Kalich-Philosoph L, Roness H, Carmely A, Fishel-Bartal M, Ligumsky H, Paglin S, et al. Cyclophosphamide triggers follicle activation and "burnout "; AS101 prevents follicle loss and preserves fertility. Sci Transl Med. 2013;5:185ra62. doi:https://doi.org/10.1126/scitranslmed.3005402.

41. Adhikari D, Liu K. Molecular mechanisms underlying the activation of mammalian primordial follicles. Endocr Rev. 2009;30(5):438-64. https://doi. org/10.1210/er.2008-0048.

42. McLaughlin EA, Mclver SC. Awakening the oocyte: controlling primordial follicle development. Reproduction. 2009;137:1-11.

43. Adhikari D, Liu K. mTOR signaling in the control of activation of primordial follicles. Cell Cycle. 2010;9:1673-4. https://doi.org/10.4161/cc.9.9.11626.

44. Jagarlamudi K, Rajkovic A. Oogenesis: transcriptional regulators and mouse models. Mol Cell Endocrinol. 2012;356:31-9. https://doi.org/10.1016/j.mce.2 011.07.049.

45. Reddy P, Zheng W, Liu K. Mechanisms maintaining the dormancy and survival of mammalian primordial follicles. Trends Endocrinol Metab. 2010; 21(2):96-103. https://doi.org/10.1016/j.tem.2009.10.001.

46. Castrillon DH, Miao L, Kollipara R, Horner JW, DePinho RA. Suppression of ovarian follicle activation in mice by the transcription factor Foxo3a. Science (80- ). 2003;301:215-8. https://doi.org/10.1126/science.1086336.

47. John GB, Gallardo TD, Shirley L, Castrillon DH. Foxo3 is a PI3K-dependent molecular switch controlling the initiation of oocyte growth. Dev Biol. 2008; 321(1):197-204. https://doi.org/10.1016/j.ydbio.2008.06.017.

48. Chang EM, Lim E, Yoon S, Jeong K, Bae S, Lee DR, et al. Cisplatin induces Overactivation of the dormant primordial follicle through PTEN/AKT/ FOXO3a pathway which leads to loss of ovarian Reserve in Mice. PLoS One. 2015;10(12):e0144245. https://doi.org/10.1371/journal.pone.0144245.

49. Goldman KN, Chenette D, Arju R, Duncan FE, Keefe DL, Grifo JA, et al. MTORC1/2 inhibition preserves ovarian function and fertility during genotoxic chemotherapy. Proc Natl Acad Sci U S A. 2017;114(12):3186-91. https://doi.org/10.1073/pnas.1617233114.

50. Lande Y, Fisch B, Tsur A, Farhi J, Prag-Rosenberg R, Ben-Haroush A, et al. Short-term exposure of human ovarian follicles to cyclophosphamide metabolites seems to promote follicular activation in vitro. Reprod BioMed Online. 2017;34:104-14. https://doi.org/10.1016/j.rbmo.2016.10.005.

51. Shai D, Aviel-Ronen S, Spector I, Raanani H, Shapira M, Gat I, et al. Ovaries of patients recently treated with alkylating agent chemotherapy indicate the presence of acute follicle activation, elucidating its role among other proposed mechanisms of follicle loss. Fertil Steril 2021;0. doi:https://doi. org/10.1016/j.fertnstert.2020.11.040.

52. de la Noval BD. Potential implications on female fertility and reproductive lifespan in BRCA germline mutation women. Arch Gynecol Obstet. 2016; 294(5):1099-103. https://doi.org/10.1007/s00404-016-4187-6.

53. Phillips K-A, Collins IM, Milne RL, Anne McLachlan S, Friedlander M, Hickey $M$, et al. Anti-Mü llerian hormone serum concentrations of women with germline BRCA1 or BRCA2 mutations. Hum Reprod. 2016;31(5):1126-32. https://doi.org/10.1093/humrep/dew044.

54. Finch A, Valentini $A$, Greenblatt $E$, Lynch HT, Ghadirian P, Armel S, et al. Frequency of premature menopause in women who carry a BRCA1 or BRCA2 mutation. Fertil Steril. 2013;99:1724-8.

55. Oktay K, Kim JY, Barad D, Babayev SN. Association of BRCA1 mutations with occult primary ovarian insufficiency: a possible explanation for the link between infertility and breast/ovarian cancer risks. J Clin Oncol. 2010;28: 240-4. https://doi.org/10.1200/JCO.2009.24.2057.

56. Weinberg-Shukron A, Rachmiel M, Renbaum P, Gulsuner S, Walsh T, Lobel $\mathrm{O}$, et al. Essential role of BRCA2 in ovarian development and function. $\mathrm{N}$ Engl J Med. 2018;379:1042-9. https://doi.org/10.1056/NEJMoa1800024.

57. sandrine $C$, abdelkader $h$, elodie $D$, héléne $C$, lambert $M$, sébastien $M$, et al. Homozygous hypomorphic BRCA2 variant in primary ovarian insufficiency without cancer or Fanconi anaemia trait. J Med Genet. 2020;0:1-10. https:// doi.org/10.1136/jmedgenet-2019-106672.

58. Dou X, Guo T, Li G, Zhou LG, Qin Y, Chen ZJ. Minichromosome maintenance complex component 8 mutations cause primary ovarian insufficiency. Fertil Steril. 2016;106:1485-1489.e2. https://doi.org/10.1016/j. fertnstert.2016.08.018.

59. Hopkins J, Hwang G, Jacob J, Sapp N, Bedigian R, Oka K, et al. Meiosisspecific Cohesin component, Stag3 is essential for maintaining centromere chromatid cohesion, and required for DNA repair and synapsis between homologous chromosomes. PLoS Genet. 2014;10:e1004413. https://doi.org/1 0.1371/journal.pgen.1004413.

60. Xiao WJ, He WB, Zhang YX, Meng LL, Lu GX, Lin G, et al. In-Frame Variants in STAG3 Gene Cause Premature Ovarian Insufficiency. Front Genet. 2019;10. https://doi.org/10.3389/fgene.2019.01016.

61. Zhe J, Chen S, Chen X, Liu Y, Li Y, Zhou X, et al. A novel heterozygous splice-altering mutation in HFM1 may be a cause of premature ovarian insufficiency. J Ovarian Res. 2019;12(1):61. https://doi.org/10.1186/s13048-01 9-0537-x.

62. Weinberg-Shukron A, Renbaum P, Kalifa R, Zeligson S, Ben-Neriah Z, Dreifuss $A$, et al. A mutation in the nucleoporin-107 gene causes XX gonadal dysgenesis. J Clin Invest. 2015;125(11):4295-304. https://doi.org/10.1172/ JCl83553.

63. De Vries L, Behar DM, Smirin-Yosef P, Lagovsky I, Tzur S, Basel-Vanagaite L. Exome sequencing reveals SYCE1 mutation associated with autosomal recessive primary ovarian insufficiency. J Clin Endocrinol Metab. 2014;99: E2129-32. https://doi.org/10.1210/jc.2014-1268.

64. De Felici M, Klinger FG, Farini D, Scaldaferri ML, lona S, Lobascio M. Establishment of oocyte population in the fetal ovary: primordial germ cell proliferation and oocyte programmed cell death. Reprod BioMed Online. 2005;10(2):182-91. https://doi.org/10.1016/S1472-6483(10)60939-X.

65. Ratts VS, Flaws JA, Kolp R, Sorenson CM, Tilly J. Ablation of bcl-2 gene expression decreases the numbers of oocytes and primordial follicles established in the post-natal female mouse gonad. Endocrinology. 1995; 136(8):3665-8. https://doi.org/10.1210/endo.136.8.7628407.

66. Wu X, Wang B, Dong Z, Zhou S, Liu Z, Shi G, et al. A NANOS3 mutation linked to protein degradation causes premature ovarian insufficiency. Cell Death Dis. 2013;4(10):e825. https://doi.org/10.1038/cddis.2013.368.

67. Santos MG, Machado AZ, Martins CN, Domenice S, Costa EMF, Nishi MY et al. Homozygous inactivating mutation in NANOS3 in two sisters with primary ovarian insufficiency; 2014. https://doi.org/10.1155/2014/787465.

68. Mansouri MR, Schuster J, Badhai J, Stattin E-L, Lö Sel R, Wehling M, et al. Alterations in the expression, structure and function of progesterone receptor membrane component-1 (PGRMC1) in premature ovarian failure. doi:https://doi.org/10.1093/hmg/ddn274.

69. Watkins WJ, Umbers AJ, Woad KJ, Harris SE, Winship IM, Gersak K, et al. Mutational screening of FOXO3A and FOXO1A in women with premature ovarian failure. Fertil Steril. 2006;86(5):1518-21. https://doi.org/10.1016/j. fertnstert.2006.03.054.

70. Wang B, Mu Y, Ni F, Zhou S, Wang J, Cao Y, et al. Analysis of FOXO3 mutation in 114 Chinese women with premature ovarian failure. Reprod BioMed Online. 2010:20:499-503.

71. Hashimoto O, Moore RK, Shimasaki S. Posttranslational processing of mouse and human BMP-15: potential implication in the determination of ovulation quota. Proc Natl Acad Sci U S A. 2005;102:5426-31. https://doi.org/10.1073/ pnas.0409533102.

72. Kumar R, Alwani M, Kosta S, Kaur R, Agarwal S. BMP15 and GDF9 gene mutations in premature ovarian failure. J Reprod Infertil. 2017;18(1):185-9. http://www.ncbi.nlm.nih.gov/pubmed/28377898. Accessed 7 Jul 2020.

73. Rossetti R, Di Pasquale E, Marozzi A, Bione S, Toniolo D, Grammatico P, et al. BMP15 mutations associated with primary ovarian insufficiency cause a defective production of bioactive protein. Hum Mutat. 2009;30:804-10. https://doi.org/10.1002/humu.20961.

74. Al-Ajoury R, Kassem E, Al-Halabi B, Moassess F, Al-Achkar W. Investigation of some genetic variations in BMP15 accompanied with premature ovarian failure (POF) in Syrian women. Middle East Fertil Soc J. 2015;20(2):91-6. https://doi.org/10.1016/j.mefs.2014.02.005.

75. Woad KJ, Pearson SM, Harris SE, Gersak K, Shelling AN. Investigating the association between inhibin alpha gene promoter polymorphisms and premature ovarian failure. Fertil Steril. 2009;91(1):62-6. https://doi.org/10.101 6/j.fertnstert.2007.11.012

76. Corre T, Schuettler J, Bione S, Marozzi A, Persani L, Rossetti R, et al. A largescale association study to assess the impact of known variants of the human INHA gene on premature ovarian failure. Hum Reprod. 2009;24(8): 2023-8. https://doi.org/10.1093/humrep/dep090. 
77. Jiang Y, Zhang Z, Cha L, Li L, Zhu D, Fang Z, et al. Resveratrol plays a protective role against premature ovarian failure and prompts female germline stem cell survival. Int J Mol Sci. 2019;20. https://doi.org/10.3390/ ijms20143605.

78. Atli M, Engin-Ustun Y, Tokmak A, Caydere M, Hucumenoglu S, Topcuoglu C. Dose dependent effect of resveratrol in preventing cisplatin-induced ovarian damage in rats: an experimental study. Reprod Biol. 2017;17:274-80. https://doi.org/10.1016/j.repbio.2017.07.001.

79. Rah H, Jeon YJ, Shim SH, Cha SH, Choi DH, Kwon H, et al. Association of miR-146aC>G, miR-196a2T>C, and miR-499A > G polymorphisms with risk of premature ovarian failure in Korean women. Reprod Sci. 2013;20:60-8. https://doi.org/10.1177/1933719112450341.

80. Kerr JB, Hutt KJ, Michalak EM, Cook M, Vandenberg CJ, Liew SH, et al. DNA damage-induced primordial follicle oocyte apoptosis and loss of fertility require TAp63-mediated induction of Puma and Noxa. Mol Cell. 2012;48(3): 343-52. https://doi.org/10.1016/j.molcel.2012.08.017.

81. Bouilly J, Bachelot A, Broutin I, Touraine P, Binart N. Novel NOBOX loss-offunction mutations account for $6.2 \%$ of cases in a large primary ovarian insufficiency cohort. Hum Mutat. 2011;32(10):1108-13. https://doi.org/10.1 002/humu.21543.

82. Bouilly J, Roucher-Boulez F, Gompel A, Bry-Gauillard H, Azibi K, Beldjord C, et al. New NOBOX mutations identified in a large cohort of women with primary ovarian insufficiency decrease KIT-L expression. J Clin Endocrinol Metab. 2015;100(3):994-1001. https://doi.org/10.1210/jc.2014-2761.

83. Zhao H, Chen ZJ, Qin Y, Shi Y, Wang S, Choi Y, et al. Transcription factor FIGLA is mutated in patients with premature ovarian failure. Am J Hum Genet. 2008;82(6):1342-8. https://doi.org/10.1016/j.ajhg.2008.04.018.

84. Zhang D, Liu Y, Zhang Z, LV P, Liu Y, Li J, et al. Basonuclin 1 deficiency is a cause of primary ovarian insufficiency. Hum Mol Genet. 2018;27:3787-800. https://doi.org/10.1093/hmg/ddy261.

85. Zhao S, Li G, Dalgleish R, Vujovic S, Jiao X, Li J, et al. Transcription factor SOHLH1 potentially associated with primary ovarian insufficiency. Fertil Steril. 2015;103:548-553.e5. https://doi.org/10.1016/j.fertnstert.2014.11.011.

86. Qin Y, Jiao X, Dalgleish R, Vujovic S, Li J, Simpson JL, et al. Novel variants in the $\mathrm{SOHLH} 2$ gene are implicated in human premature ovarian failure. Fertil Steril. 2014;101:1104-1109.e6.

87. Wang B, Mu Y, Ni F, Zhou S, Wang J, Cao Y, et al. Analysis of FOXO3 mutation in 114 Chinese women with premature ovarian failure. Reprod BioMed Online. 2010;20(4):499-503. https://doi.org/10.1016/j.rbmo.2010.01.008.

88. Di Pasquale E, Rossetti R, Marozzi A, Bodega B, Borgato S, Cavallo L, et al. Identification of new variants of human BMP15 gene in a large cohort of women with premature ovarian failure. J Clin Endocrinol Metab. 2006;91(5): 1976-9. https://doi.org/10.1210/jc.2005-2650.

89. Wang B, Li L, Zhu Y, Zhang W, Wang X, Chen B, et al. Sequence variants of KHDRBS1 as high penetrance susceptibility risks for primary ovarian insufficiency by mis-regulating mRNA alternative splicing. Hum Reprod. 2017:32(10):2138-46. https://doi.org/10.1093/humrep/dex263.

90. Murray A, Schoemaker MJ, Bennett CE, Ennis S, MacPherson JN, Jones M, et al. Population-based estimates of the prevalence of FMR1 expansion mutations in women with early menopause and primary ovarian insufficiency. Genet Med. 2014;16(1):19-24. https://doi.org/10.1038/gim.2013.64.

91. Ponder B, Pharoah PDP, Ponder BAJ, Lipscombe JM, Basham V, Gregory J, et al. Prevalence and penetrance of BRCA1 and BRCA2 mutations in a population-based series of breast cancer cases. Br J Cancer. 2000;83(10): 1301-8. https://doi.org/10.1054/bjoc.2000.1407.

92. Desai S, Wood-Trageser M, Matic J, Chipkin J, Jiang H, Bachelot A, et al. MCM8 and MCM9 Nucleotide Variants in Women with Primary Ovarian Insufficiency. J Clin Endocrinol Metab. 2016;102:jc.2016-565. https://doi. org/10.1210/jc.2016-2565

93. Yang Y, Guo T, Liu R, Ke H, Xu W, Zhao S, et al. FANCL gene mutations in premature ovarian insufficiency. Hum Mutat. 2020;41:1033-41. https://doi. org/10.1002/humu.23997.

94. Qin Y, Zhao H, Kovanci E, Simpson JL, Chen ZJ, Rajkovic A. Mutation analysis of NANOS3 in 80 Chinese and 88 Caucasian women with premature ovarian failure. Fertil Steril. 2007;88(5):1465-7. https://doi.org/10.1016/j. fertnstert.2007.01.020.

95. Lucas B, Sousa A, Nishi MY, Santos G, Brito N, Domenice S, et al. Mutation analysis of NANOS3 in Brazilian women with primary ovarian failure. https:// doi.org/10.6061/clinics/2016(12)03.

96. Wang JL, Li SL, Qin YY, Chen ZJ. Analysis of progesterone receptor membrane component 1 mutation in Han Chinese women with premature ovarian failure. Reprod BioMed Online. 2014;29(5):640-3. https://doi.org/10.1 016/j.rbmo.2014.08.001.

97. Wang J, Zhang $W$, Jiang H, Wu BL. Mutations in HFM1 in recessive primary ovarian insufficiency. N Engl J Med. 2014;370:972-4. https://doi.org/10.1056/ NEJMc1310150

98. Murray A, Schoemaker MJ, Bennett CE, Ennis S, Macpherson JN, Jones M, et al. Population-based estimates of the prevalence of FMR1 expansion mutations in women with early menopause and primary ovarian insufficiency; 2013. https://doi.org/10.1038/gim.2013.64.

99. Yang L, Duan $R$, Chen D, Wang J, Chen D, Jin P. Fragile X mental retardation protein modulates the fate of germline stem cells in Drosophila. Hum Mol Genet. 2007;16:1814-20. https://doi.org/10.1093/hmg/ddm129.

100. Welt CK, Smith PC, Taylor AE. Evidence of early ovarian aging in fragile $X$ Premutation carriers. J Clin Endocrinol Metab. 2004;89:4569-74. https://doi. org/10.1210/jc.2004-0347.

101. Sanger F, Nicklen S, Coulson AR. DNA sequencing with chain-terminating inhibitors. Proc Natl Acad Sci U S A. 1977;74(12):5463-7. https://doi.org/10.1 073/pnas.74.12.5463.

102. Barzon L, Lavezzo E, Militello V, Toppo S, Palù G. Applications of nextgeneration sequencing technologies to diagnostic virology. Int J Mol Sci. 2011;12:7861-84. https://doi.org/10.3390/ijms12117861.

103. LaDuca H, Polley EC, Yussuf A, Hoang L, Gutierrez S, Hart SN, et al. A clinical guide to hereditary cancer panel testing: evaluation of gene-specific cancer associations and sensitivity of genetic testing criteria in a cohort of 165,000 high-risk patients. Genet Med. 2020;22:407-15. https://doi.org/10.1038/s4143 6-019-0633-8.

104. Pelosi E, Forabosco A, Schlessinger D. Genetics of the ovarian reserve. Front Genet. 2015;6. https://doi.org/10.3389/fgene.2015.00308.

105. Telenti A, Pierce LCT, Biggs WH, Di lulio J, Wong EHM, Fabani MM, et al. Deep sequencing of 10,000 human genomes. Proc Natl Acad Sci U S A. 2016;113:11901-6. https://doi.org/10.1073/pnas.1613365113.

106. Hegde M, Santani A, Mao R, Ferreira-Gonzalez A, Weck KE, Voelkerding KV. Development and validation of clinical whole-exome and whole-genome sequencing for detection of germline variants in inherited disease. Arch Pathol Lab Med. 2017;141:798-805.

107. Langmead B, Nellore A. Cloud computing for genomic data analysis and collaboration. Nat Rev Genet. 2018;19(4):208-19. https://doi.org/10.1038/ nrg.2017.113

108. Angiuoli SV, Matalka M, Gussman A, Galens K, Vangala M, Riley DR, et al. CloVR: a virtual machine for automated and portable sequence analysis from the desktop using cloud computing. BMC Bioinformatics. 2011;12:356. https://doi.org/10.1186/1471-2105-12-356.

109. Ma T, Zhang A. Omics informatics: from scattered individual software tools to integrated workflow management systems. IEEE/ACM Trans Comput Biol Bioinforma. 2017;14(4):926-46. https://doi.org/10.1109/ TCBB.2016.2535251.

110. McKenna A, Hanna M, Banks E, Sivachenko A, Cibulskis K, Kernytsky A, et al. The genome analysis toolkit: a MapReduce framework for analyzing nextgeneration DNA sequencing data. Genome Res. 2010;20(9):1297-303. https://doi.org/10.1101/gr.107524.110.

111. Beck $L$, Sileo M, Copperman A. The average cost of fertility preservation for female cancer patients; 2010.

112. Patel B, Parets $S$, Akana M, Kellogg G, Jansen M, Chang C, et al. Comprehensive genetic testing for female and male infertility using nextgeneration sequencing. J Assist Reprod Genet. 2018;35(8):1489-96. https:// doi.org/10.1007/s10815-018-1204-7.

113. Hamblin A, Wordsworth S, Fermont JM, Page S, Kaur K, Camps C, et al. Clinical applicability and cost of a 46-gene panel for genomic analysis of solid tumours: retrospective validation and prospective audit in the UK National Health Service. PLoS Med. 2017;14(2):e1002230. https://doi.org/1 0.1371/journal.pmed.1002230.

114. Manchanda R, Sun L, Brentnall A, Patel S, Buist DSM, Bowles EJA, et al. A costeffectiveness analysis of multigene testing for all patients with breast cancer. JAMA Oncol. 2019:5:1718-30. https:/doi.org/10.1001/jamaoncol.2019.3323.

115. Asphaug L, Melberg HO. The Cost-Effectiveness of Multigene Panel Testing for Hereditary Breast and Ovarian Cancer in Norway.

116. Collins SC. Precision reproductive medicine: multigene panel testing for infertility risk assessment. J Assist Reprod Genet. 2017;34:967-73. https://doi. org/10.1007/s10815-017-0938-y.

117. Rudnicka E, Kruszewska J, Klicka K, Kowalczyk J, Grymowicz M, Skórska J, et al. Premature ovarian insufficiency - aetiopathology, epidemiology, and 
diagnostic evaluation. Przeglad Menopauzalny. 2018;17:105-8. https://doi. org/10.5114/pm.2018.78550.

118. Liu X-C, Han M-X, XU Y, Wang H-Y, Li B. Knockdown of the premature ovarian insufficiency candidate gene NUP107 in ovarian granulosa cells affects cell functions, including receptor expression and estrogen synthesis. Reprod Dev Med. 2019;3:133. https://doi.org/10.4103/2096-2 924.268158

119. Ren Y, Diao F, Katari S, Yatsenko S, Jiang H, Wood-Trageser MA, et al. Functional study of a novel missense single-nucleotide variant of NUP107 in two daughters of Mexican origin with premature ovarian insufficiency. Mol Genet Genomic Med. 2018;6(2):276-81. https://doi.org/10.1002/mgg3.345.

120. Patiño LC, Silgado D, Laissue P. A potential functional association between mutant BMPR2 and primary ovarian insufficiency. Syst Biol Reprod Med. 2017;63:145-9. https://doi.org/10.1080/19396368.2017.1291767.

121. Shimasaki S, Moore RK, Otsuka F, Erickson GF. The bone morphogenetic protein system in mammalian reproduction. Endocr Rev. 2004;25(1):72-101. https://doi.org/10.1210/er.2003-0007.

122. F O. Multifunctional bone morphogenetic protein system in endocrinology. Acta Med Okayama. 2013;67. doi:https://doi.org/10.18926/AMO/49665.

123. Familial primary ovarian insufficiency associated with a SYCE1 point mutation: Defective meiosis elucidated in humanized mice. doi:https://doi. org/10.1101/2020.02.07.938639.

124. McGuire MM, Bowden W, Engel NJ, Ahn HW, Kovanci E, Rajkovic A. Genomic analysis using high-resolution single-nucleotide polymorphism arrays reveals novel microdeletions associated with premature ovarian failure. Fertil Steril. 2011;95:1595-600. https://doi.org/10.1016/j.fertnstert.2010.12.052.

125. Caburet S, Arboleda VA, Llano E, Overbeek PA, Barbero JL, Oka K, et al. Mutant Cohesin in premature ovarian failure. N Engl J Med. 2014;370:943-9. https://doi.org/10.1056/NEJMoa1309635.

126. Le Quesne SP, Williams HJ, James C, Tekman M, Stanescu HC, Kleta R, et al. STAG3 truncating variant as the cause of primary ovarian insufficiency. Eur J Hum Genet. 2016;24(1):135-8. https://doi.org/10.1038/ejhg.2015.107.

127. Heddar A, Dessen P, Flatters D, Misrahi M. Novel STAG3 mutations in a Caucasian family with primary ovarian insufficiency. Mol Gen Genomics. 2019;294(6):1527-34. https://doi.org/10.1007/s00438-019-01594-4.

128. He WB, Banerjee S, Meng LL, Du J, Gong F, Huang H, et al. Whole-exome sequencing identifies a homozygous donor splice-site mutation in STAG3 that causes primary ovarian insufficiency. Clin Genet. 2018:93:340-4. https:// doi.org/10.1111/cge.13034.

129. Kneitz B, Cohen PE, Avdievich E, Zhu L, Kane MF, Hou H, et al. MutS homolog 4 localization to meiotic chromosomes is required for chromosome pairing during meiosis in male and female mice. Genes Dev. 2000;14(9):1085-97. https://doi.org/10.1101/gad.14.9.1085.

130. Carlosama C, Eva Elzaiat M€, Pati No LC, Mateus HE, Veitia RA, Laissue P. A homozygous donor splice-site mutation in the meiotic gene MSH4 causes primary ovarian insufficiency. doi:https://doi.org/10.1093/hmg/ddx199.

131. Mutations in MSH5 in primary ovarian insufficiency. https:/www.ncbi.nlm. nih.gov/pmc/articles/PMC5393145/. Accessed 9 Aug 2020.

132. Yoshida K, Kondoh G, Matsuda Y, Habu T, Nishimune Y, Morita T. The mouse RecA-like gene Dmc1 is required for homologous chromosome synapsis during meiosis. Mol Cell. 1998;1:707-18. https://doi.org/10.1016/S1 097-2765(00)80070-2.

133. He WB, Tu CF, Liu Q, Meng LL, Yuan SM, Luo AX, et al. DMC1 mutation that causes human non-obstructive azoospermia and premature ovarian insufficiency identified by whole-exome sequencing. J Med Genet. 2018;55: 198-204. https://doi.org/10.1136/jmedgenet-2017-104992.

134. Zhou Y, Qin Y, Qin Y, Xu B, Guo T, Ke H, et al. Wdr62 is involved in female meiotic initiation via activating JNK signaling and associated with POI in humans. PLoS Genet. 2018;14:e1007463. https://doi.org/10.1371/journal. pgen. 1007463 .

135. Simon AM, Goodenough DA, Li E, Paul DL. Female infertility in mice lacking connexin 37. Nature. 1997;385:525-9. https://doi.org/10.1038/385525a0.

136. Bachelot A, Gilleron J, Meduri G, Guberto M, Dulon J, Boucherie S, et al. A common African variant of human connexin 37 is associated with Caucasian primary ovarian insufficiency and has a deleterious effect in vitro. Int J Mol Med. 2018;41:640-8. https://doi.org/10.3892/ijmm.2017.3257.

137. Pepling ME, Spradling AC. Mouse ovarian germ cell cysts undergo programmed breakdown to form primordial follicles. Dev Biol. 2001;234: 339-51. https://doi.org/10.1006/dbio.2001.0269.

138. Moore GPM, Lintern MS. Transcription of the mouse oocyte genome. Biol Reprod. 1978;18(5):865-70. https://doi.org/10.1095/biolreprod18.5.865.
139. Moriwaki M, Moore B, Mosbruger T, Neklason DW, Yandell M, Jorde LB, et al. POLR2C mutations are associated with primary ovarian insufficiency in women J Endocr Soc. 2017;1(3):162-73. https://doi.org/10.1210/js.2016-1014.

140. Franca MM, Han X, Funari MFA, Lerario AM, Nishi MY, Fontenele EGP, et al. Exome sequencing reveals the POLR3H gene as a novel cause of primary ovarian insufficiency. J Clin Endocrinol Metab. 2019;104(7):2827-41. https:// doi.org/10.1210/jc.2018-02485.

141. Chen A, Tiosano D, Guran T, Baris HN, Bayram Y, Mory A, et al. Mutations in the mitochondrial ribosomal protein MRPS22 lead to primary ovarian insufficiency. Hum Mol Genet. 2018;27(11):1913-26. https://doi.org/10.1093/ hmg/ddy098.

142. Vanorny DA, Prasasya RD, Chalpe AJ, Kilen SM, Mayo KE. Notch signaling regulates ovarian follicle formation and coordinates follicular growth. Mol Endocrinol. 2014;28(4):499-511. https://doi.org/10.1210/me.2013-1288.

143. Patiño LC, Beau I, Morel A, Delemer B, Young J, Binart N, et al. Functional evidence implicating NOTCH2 missense mutations in primary ovarian insufficiency etiology. Hum Mutat. 2019;40:25-30. https://doi.org/10.1002/ humu.23667.

144. Song ZH, Yu HY, Wang P, Mao GK, Liu WX, Li MN, et al. Germ cell-specific Atg7 knockout results in primary ovarian insufficiency in female mice. Cell Death Dis. 2015;6:e1589. https://doi.org/10.1038/cddis.2014.559.

145. Delcour C, Amazit L, Patino LC, Magnin F, Fagart J, Delemer B, et al. ATG7 and ATG9A loss-of-function variants trigger autophagy impairment and ovarian failure. Genet Med. 2019;21(4):930-8. https://doi.org/10.1038/s41436-018-0287-y.

146. Suh EK, Yang A, Kettenbach A, Bamberger C, Michaelis AH, Zhu Z, et al. p63 protects the female germ line during meiotic arrest. Nature. 2006;444(7119): 624-8. https://doi.org/10.1038/nature05337.

147. Wan L, Han J, Liu T, Dong S, Xie F, Chen H, et al. Scaffolding protein SPIDR/ KIAA0146 connects the bloom syndrome helicase with homologous recombination repair. Proc Natl Acad Sci U S A. 2013;110(26):10646-51. https://doi.org/10.1073/pnas.1220921110.

148. Smirin-Yosef P, Zuckerman-Levin N, Tzur S, Granot Y, Cohen L, Sachsenweger J, et al. A Biallelic mutation in the homologous recombination repair gene SPIDR is associated with human gonadal dysgenesis. 2017.

149. Hantash FM, Goos DM, Crossley B, Anderson B, Zhang K, Sun W, et al. FMR1 premutation carrier frequency in patients undergoing routine populationbased carrier screening: insights into the prevalence of fragile X syndrome, fragile $X$-associated tremor/ataxia syndrome, and fragile $X$-associated primary ovarian insufficiency in the United States. Genet Med. 2011;13(1): 39-45. https://doi.org/10.1097/GIM.0b013e3181fa9fad.

150. Schwartz CE, Dean J, Howard-Peebles PN, Bugge M, Mikkelsen M, Tommerup N, et al. Obstetrical and gynecological complications in fragile $X$ carriers: a multicenter study. Am J Med Genet. 1994;51(4):400-2. https://doi. org/10.1002/ajmg.1320510419.

151. Allingham-Hawkins DJ, Babul-Hirji R, Chitayat D, Holden JJA, Yang KT, Lee C, et al. Fragile $X$ premutation is a significant risk factor for premature ovarian failure: the international collaborative POF in fragile $X$ study - preliminary data. Am J Med Genet. 1999;83(4):322-5. https://doi.org/10.1002/(SICI)10968628(19990402)83:4<322::AID-AJMG17>3.0.CO;2-B.

152. Wheeler AC, Bailey DB, Berry-Kravis E, Greenberg J, Losh M, Mailick M, et al. Associated features in females with an FMR1 premutation. J Neurodev Disord. 2014;6(1):30. https://doi.org/10.1186/1866-1955-6-30.

153. Easton DF, Ford D, Timothy Bishop ' D. Breast and Ovarian Cancer Incidence in BRCA I-Mutation Carriers 1995.

\section{Publisher's Note}

Springer Nature remains neutral with regard to jurisdictional claims in published maps and institutional affiliations. 